\title{
KANDUNGAN GAS METANA BATUBARA DAERAH NIBUNG, KABUPATEN MUSI RAWAS, PROVINSI SUMATERA SELATAN
}

\author{
Oleh: \\ Sigit Arso W. \\ Pusat Sumber Daya Geologi \\ Jin. Soekarno - Hatta No. 444 Bandung
}

SARI

Gas metana $\left(\mathrm{CH}_{4}\right)$ merupakan salah satu gas yang terdapat dalam batubara yang dapat dimanfaatkan sebagai sumber energi. Berdasarkan perhitungan rata-rata dengan metode desorption test, gas metana $\left(\mathrm{CH}_{4}\right)$ di dalam conto batubara Formasi Muaraenim adalah 0,48 $\mathrm{m}^{3} /$ ton (Lapisan Mangus), $0,46 \mathrm{~m}^{3} /$ ton (Lapisan Suban) dan $0,20 \mathrm{~m}^{3} /$ ton (Lapisan Petai). Sedangkan untuk analisis adsorption isotherm diketahui bahwa kandungan abu Lapisan Mangus dan Suban adalah sebesar 2,07\% dan 59,63\%.

Kandungan gas metana Lapisan Mangus lebih besar dikarenakan kandungan abu Lapisan Mangus lebih sedikit dibandingkan dua lapisan lainnya.

Kata Kunci : Nibung, Formasi Muaraenim, Batubara, Gas Metana $\left(\mathrm{CH}_{4}\right)$

\section{ABSTRACT}

Methane $\left(\mathrm{CH}_{4}\right)$ is one of gas found in coal that can be use as energy resources. Based on calculation with desorption test method, methane $\left(\mathrm{CH}_{4}\right)$ in coal sample on Muaraenim Formation is about $0.48 \mathrm{~m}^{3} /$ ton (Seam Mangus), $0.46 \mathrm{~m}^{3} /$ ton (Seam Suban) and $0.20 \mathrm{~m}^{3} /$ ton (Seam Petai). The analysis of adsorption isotherm is produce data that the ash content on Seam Mangus and Suban are $2.07 \%$ and $59.63 \%$, respective.

Methane in Seam Mangus has a higher content because ash content on Seam Mangus is lessthan two other seam.

Keyword : Nibung, Muaraenim Formation, Coal, Methane $\left(\mathrm{CH}_{4}\right)$

\section{PENDAHULUAN}

Batubara merupakan salah satu sumber daya alam yang dapat digunakan untuk sumber energi. Sumber energi yang terdapat dalam batubara adalah energi panas yang pemanfaataannya mempunyai cakupan yang sangat luas diantaranya untuk bahan bakar, pembangkit listrik, dan lain sebagainya. Selain itu batubara juga memiliki kandungan gas diantaranya $\mathrm{CO}_{2}$, $\mathrm{CH}_{4}, \mathrm{H}_{2}, \mathrm{O}_{2}, \mathrm{~N}_{2}$ dan lain-lain. Kandungan gas tersebut ada yang dapat dimanfaatkan sebagai sumber energi dan ada pula yang tidak. Salah satu gas yang dapat dimanfaatkan untuk sumber energi adalah
$\mathrm{CH}_{4}$ atau metana.

Metana menurut wikipedia adalah hidrokarbon paling sederhana yang berbentuk gas dengan rumus kimia $\mathrm{CH}_{4}$. Keberadaan metana di alam diantaranya terdapat di tumpukan sampah, kotoran hewan, batubara dan lain sebagainya

Gas metana batubara merupakan campuran gas hidrokarbon dengan komposisi dominan gas metana $\left(\mathrm{CH}_{4}\right)(90-$ 95\%) dan gas lainnya seperti karbondioksida $\left(\mathrm{CO}_{2}\right)$ dan nitrogen $\left(\mathrm{N}_{2}\right)$ dalam jumlah yang sedikit (Alan A. Bayrak, 2010). 
Penelitian ini mempunyai tujuan untuk mengetahui kandungan gas metana $\left(\mathrm{CH}_{4}\right)$ dalam batubara di Formasi Muaraenim.

Metode yang digunakan untuk mengetahui kandungan gas metana dalam batubara diantaranya adalah desorption test, analisis adsorption isotherm dan gas chromatograph. Desorption test digunakan untuk mengetahui jumlah total kandungan gas yang terdapat dalam batubara. Metode ini mengadopsi metode dari USGS, secara matematis dapat digambarkan sebagai berikut:

$$
\mathbf{Q}_{\mathbf{T}}=\mathbf{Q}_{1}+\mathbf{Q}_{\mathbf{2}}+\mathbf{Q}_{3}
$$

dimana ;

$$
\begin{aligned}
& \mathrm{Q}_{\mathrm{T}}: \text { Jumlah Total Kandungan Gas } \\
& \quad(\mathrm{cc}) \\
& \mathrm{Q}_{1}: \text { Kandungas Gas yang Hilang } \\
& \quad \text { Lost Gas) (cc) } \\
& \mathrm{Q}_{2}: \begin{array}{l}
\text { Kandungan Gas yang Diukur } \\
\text { dalam canister (cc) }
\end{array} \\
& \mathrm{Q}_{3}: \text { Kandungan Gas Sisa }
\end{aligned}
$$$$
\text { (Saat Crusher) (cc) }
$$

Hasil $Q_{1}$ atau lost gas didapatkan dari analisa regresi linier yang didapatkan setelah pengukuran gas di canister atau $Q_{2}$ telah selesai dilakukan. $Q_{2}$ didapat dari hasil pengukuran gas yang keluar dari canister sedangkan untuk $Q_{3}$ dihasilkan dari pengukuran gas yang keluar dari batubara pada saat batubara di crusheratau digerus.

Analisis berikutnya adalah adsorption isotherm dilakukan berdasarkan metode volumetric dari CSIRO untuk menentukan kapasitas serap (sorption capacity) batubara sebagai fungsi tekanan. Atau dengan kata lain adsorption isotherm diekspresikan sebagai hubungan antara volume gas terserap dengan tekanan gas tersebut, dalam hal ini gas yang digunakan adalah gas metana $\left(\mathrm{CH}_{4}\right) \pm 99,9 \%$ purity. Sedangkan gas chromatograph digunakan untuk mengetahui komposisi gas yang terdapat dalam lapisan batubara.

Sebanyak 26 conto batubara yang dianalisa kandungan gasnya diambil dari satu titik bor (NBG-01) dengan total kedalaman $391 \mathrm{~m}$. Lokasi titik bor terletak di koordinat 1030229,80" Bujur Timur dan 22741,34" Lintang Selatan dimana secara administatif termasuk ke dalam wilayah Kabupaten Musi Rawas, Provinsi Sumatera Selatan (Gambar 1).

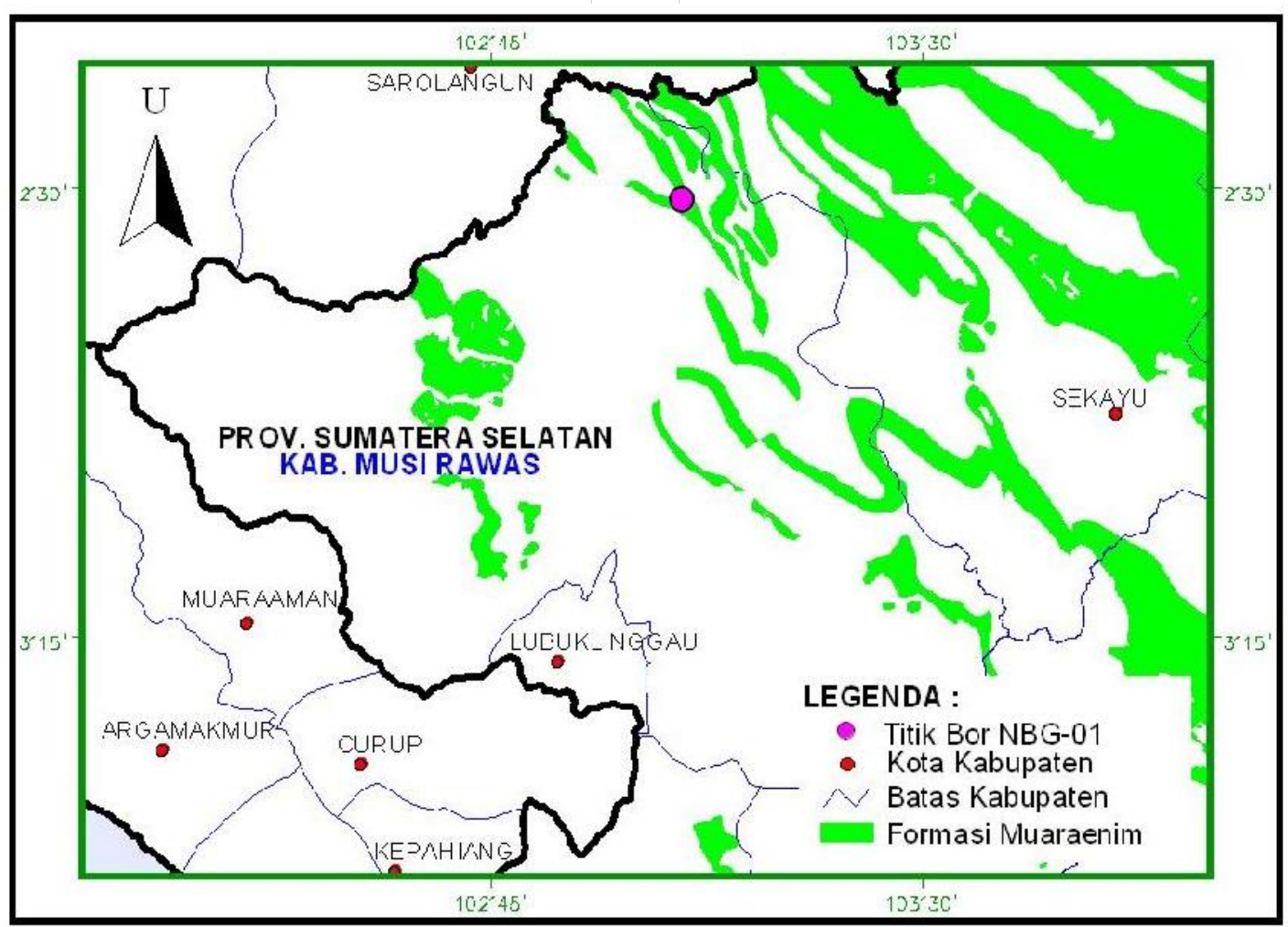

Gambar 1. Peta Lokasi Titik Bor Daerah Nibung 
Geologi

Daerah penelitian termasuk di dalam Peta Geologi Lembar Sarolangun, Sumatera Skala $1: 250.000$ (N. Suwarna, Suharsono, S. Gafoer, T. C. Amin, Kusnama dan B. Hermanto, 2007).

Geologi daerah penelitian termasuk dalam Cekungan Sumatera Selatan. Menurut de Coster (1974), Cekungan Sumatera Selatan dan Cekungan Sumatera Tengah adalah suatu cekungan besar yang dicirikan oleh kesamaan sedimentasi batuan dan dipisahkan oleh Tinggian Tigapuluh yang terbentuk akibat pergerakan ulang sesar bongkah pada batuan berumur Pra Tersier diikuti oleh kegiatan volkanik.

\section{Kandungan Gas Metana Daerah Nibung}

Conto batubara daerah Nibung termasuk ke dalam Anggota M2, Formasi Muaraenim. Sebanyak 26 conto batubara diambil dari titik bor NBG-01 kemudian dimasukkan ke dalam canister dan telah dilakukan beberapa analisis diantaranya desorption test, adsorption test dan gas chromatograph dimana sebanyak 20 conto termasuk ke dalam Lapisan Mangus, 5 conto Lapisan Suban dan 1 conto Lapisan Petai. Kedalaman dan ketebalan batubara untuk masing-masing lapisan tersebut adalah sebagai berikut;

Lapisan Mangus terdapat di kedalaman 237, 58 - 251,22 m dengan ketebalan 13, $64 \mathrm{~m}$, Lapisan Suban terdapat di kedalaman 275,85-278,55 m dengan ketebalan 2,70 m dan Lapisan Petai terdapat di kedalaman $282,15-283,15 \mathrm{~m}$ dengan ketebalan $1,00 \mathrm{~m}$ (Tabel 1).

Conto batubara yang dianalisis hanya pada kedalaman $237-283 \mathrm{~m}$, hal ini dikarenakan pada kedalaman tersebut diperkirakan memiliki potensi kandungan gas $\mathrm{CH}_{4}$ yang cukup besar.

\begin{tabular}{|c|c|c|c|c|c|c|c|}
\hline \multirow{2}{*}{\multicolumn{2}{|c|}{$\mathbf{U} \mathbf{m} \mathbf{u} \mathbf{r}$}} & \multirow{2}{*}{\multicolumn{2}{|c|}{ Formasi }} & \multicolumn{2}{|c|}{$\begin{array}{l}\text { Daerah Nibung - Jambi - Sumatra Selatan } \\
\text { (Modifikasi dari Sumaatmadja, dkk-, 2001) }\end{array}$} & \multicolumn{2}{|c|}{$\begin{array}{l}\text { Cekungan Sumatra Selatan } \\
\text { (Shell, 1978) }\end{array}$} \\
\hline & & & & Deskripsĩ & Lapisan & Lapisan & Deskrīpsi \\
\hline \multicolumn{2}{|c|}{ Pllosen } & \multicolumn{2}{|c|}{$\begin{array}{l}\text { Kasal } \\
\text { (QTK) }\end{array}$} & $\begin{array}{l}\text { Lempung tufaan, pas'i tufaan, wama } \\
\text { terang, pasir batuapungan, lensa- ensa } \\
\text { batubara }\end{array}$ & & \multirow[b]{2}{*}{$\begin{array}{l}\text { Eemakat/Eabat } \\
\text { Eenim } \\
\text { Entan } \\
\end{array}$} & $\begin{array}{l}\text { Batupasir tufaan, lempung tufaan, } \\
\text { abu-abu putlh, biru-hljau, batuapung }\end{array}$ \\
\hline \multirow{7}{*}{$\begin{array}{l}\text { c } \\
. \\
0 \\
0 \\
- \\
\mathbf{x}\end{array}$} & \multirow{3}{*}{$\begin{array}{l}\frac{2}{5} \\
\frac{2}{2}\end{array}$} & \multirow{4}{*}{ 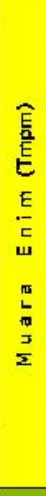 } & M4 & $\begin{array}{l}\text { Batulempung hijau-biru, abu-abu, kayá } \\
\text { material volkanik, s sipan batupasir } \\
\text { abu-abu hijau dan puth, beberapa } \\
\text { laplsan batubara. Tebal } 180 \quad 240 \mathrm{~m} \text {. }\end{array}$ & & & $\begin{array}{l}\text { Lempung tufaan, hijau-biru, dan lempung } \\
\text { pasiran, pasir halus-kasar, abu-abu \& } \\
\text { putlh, gaukonitan, laplsan batuapung }\end{array}$ \\
\hline & & & M3 & $\begin{array}{l}\text { Perselingan batupasir abu abu muda } \\
\text { dan batulempung abu-abu hijau serta } \\
\text { sisipan lapisan batubara, batulempung } \\
\text { dan batupas r mengandung nodul } \\
\text { ironstone dengan rongga-rongga gas. } \\
\text { Tebal } 115365 \mathrm{~m} \text {. } \\
\end{array}$ & Bentuang & $\begin{array}{l}\text { Benuang } \\
\text { Burung }\end{array}$ & $\begin{array}{l}\text { Perse ingan batupasir dan batulanąu } \\
\text { menindih lempung biru-hijau dan } \\
\text { abu-abu, horizon batupasir tebal 3-6 m }\end{array}$ \\
\hline & & & $M 2$ & $\begin{array}{l}\text { Persel ingan botulempung caklat degn } \\
\text { batupasir abu-abu kehijauan, lapisan } \\
\text { batubara dengan kandungan tuf biotit } \\
\text { terpudarkan. } \\
\text { Tebal } 45->100 \mathrm{~m} \text {. }\end{array}$ & Mangus ${ }_{2}^{1}$ & ${ }_{2}^{1}$ Mangus & $\begin{array}{l}\text { Batulempung caklat, abu-abu, } \\
\text { batulempung pass ran, batupasir halus, } \\
\text { hijau-abu-abu di bagian bawah, } \\
\text { sedimen interseam Mangus batupasir } \\
\text { tufaan mengandung biotiti }\end{array}$ \\
\hline & \multirow[b]{2}{*}{$\begin{array}{l}5 \\
\text { an } \\
\text { an } \\
c \\
y \\
1\end{array}$} & & M1 & $\begin{array}{l}\text { Batupasır hijau-b ru, batulempung hijau } \\
\text { dan slspan batulanau. } \\
\text { Tebal } 100-150 \mathrm{~m} \text {. }\end{array}$ & Merapl & Merspi & $\begin{array}{l}\text { Batupasir, batu anau, batu empung } \\
\text { caklat, abu-abu, dengan batupasir } \\
\text { glaukonitan }\end{array}$ \\
\hline & & \multicolumn{2}{|c|}{$\begin{array}{c}\text { Air } \\
\text { Benakat } \\
\text { (Tma) }\end{array}$} & $\begin{array}{l}\text { Batulempung abu-abu kecoklatan, } \\
\text { batupasir abu abu kekuningan, } \\
\text { glaukonitan, mengandung angkang } \\
\text { moluska darı foram n fera }\end{array}$ & & & $\begin{array}{l}\text { Batulempung abu-abu - coklat, biru, } \\
\text { serpih pasiran hijeu - abu-gbu, h'jau, } \\
\text { glaukonitan }\end{array}$ \\
\hline & & \multirow{2}{*}{\multicolumn{2}{|c|}{$\begin{array}{l}\text { Gumal } \\
\text { (Tmg) }\end{array}$}} & Perselingan serpih, napal dan & & & \multirow{2}{*}{$\begin{array}{l}\text { Perse ingan serpih, napal dan } \\
\text { batu empung gampingan }\end{array}$} \\
\hline & $\begin{array}{l}\overline{5} \\
\vdots \\
3\end{array}$ & & & $\begin{array}{l}\text { batulempung. Napal setempat } \\
\text { mengandung pirit. }\end{array}$ & & & \\
\hline
\end{tabular}

Gambar 2. Kolom Stratigrafi Daerah Nibung (Tim Pemboran Dalam Nibung, 2010) 
Dari perhitungan dengan menggunakan metode desorption test didapatkan hasil rata-rata total kandungan gas adalah sebagai berikut ; Lapisan Mangus $1,14 \mathrm{~m}^{3} /$ ton, Lapisan Suban 1,08 $\mathrm{m}^{3} /$ ton dan Lapisan Petai $0,99 \mathrm{~m}^{3} /$ ton (Tabel 2). Sedangkan untuk analisis adsorption isotherm hanya dilakukan di dua lapisan batubara saja yaitu Lapisan Mangus dan Suban. Lapisan Mangus dan Suban mempunyai kemampuan untuk menyimpan gas mencapai $12,43 \mathrm{~m}^{3} /$ ton dan $6,15 \mathrm{~m}^{3} /$ ton pada tekanan 474 dan 617 psi (Tabel 3).

Hasil analisis rata-rata gas chromatograph untuk ketiga lapisan tersebut adalah sebagai berikut : Lapisan Mangus, $\mathrm{O}_{2}$
$7,79 \% ; \mathrm{N}_{2} 49,28 \% ; \mathrm{CH}_{4} 42,21 \%$; $\mathrm{CO} 0,34 \%$; $\mathrm{CO}_{2} 0,07 \%$; dan $\mathrm{H}_{2} 0,31 \%$. Lapisan Suban, $\mathrm{O}_{2} 3,07 \% ; \mathrm{N}_{2}$ 53,30\%; $\mathrm{CH}_{4} 43,50 \%$; $\mathrm{CO}$ 0,00\%; $\mathrm{CO}_{2}$ 0,13\%; dan $\mathrm{H}_{2}$ 0,00\%. Lapisan Petai, $\mathrm{O}_{2} 4,55 \% ; \mathrm{N}_{2} 74,00 \% ; \mathrm{CH}_{4} 20,66 \%$; $\mathrm{CO} 0,00 \% ; \mathrm{CO}_{2} 0,21 \%$; dan $\mathrm{H}_{2} 0,58 \%$

Berdasarkan hasil analisis kimia diketahui pula bahwa nilai kalori untuk Lapisan Mangus berkisar antara 5542 $6346 \mathrm{kal} / \mathrm{gr}$ dan Lapisan Suban antara 3161 $-6135 \mathrm{kal} / \mathrm{gr}$. Sedangkan untuk kandungan abu Lapisan Mangus berkisar antara 2,25 $17,26 \%$ dan Lapisan Suban antara 3,00 $48,54 \%$ (Tabel 6).

Tabel 1.

Data Kedalaman Lapisan Batuba di Titik Bor NBG-01

(Tim Pemboran Dalam Nibung, 2010)

\begin{tabular}{|c|c|c|c|c|c|c|c|}
\hline \multirow[t]{2}{*}{$\begin{array}{c}\text { LUBANG } \\
\text { BOR }\end{array}$} & \multicolumn{2}{|c|}{ KOORDINAT } & \multicolumn{2}{|c|}{$\begin{array}{l}\text { KEDALAMAN } \\
\text { LAPISAN } \\
\text { BATUBARA (M) }\end{array}$} & \multirow[t]{2}{*}{$\begin{array}{c}\text { TEBAL } \\
\text { (M) }\end{array}$} & \multirow[t]{2}{*}{ LAPISAN } & \multirow[t]{2}{*}{ KET. } \\
\hline & BT & LS & ATAP & LANTAI & & & \\
\hline \multirow{10}{*}{ NBG-01 } & \multirow{10}{*}{$103^{\circ} 02^{\prime} 29,80^{\prime \prime}$} & \multirow{10}{*}{$2^{\circ} 27^{\prime} 41,34^{\prime \prime}$} & 75,55 & 78,65 & 3,10 & 1 & \\
\hline & & & 157,20 & 159,05 & 1,85 & 2 & \\
\hline & & & 179,50 & 180,00 & 0,50 & 3 & \\
\hline & & & 198,75 & 199,35 & 0,60 & 4 & \\
\hline & & & 217,25 & 220,50 & 3,30 & 5 & \\
\hline & & & 237,58 & 251,22 & 13,64 & 6 (Mangus) & \multirow{3}{*}{$\begin{array}{l}\text { Conto } \\
\text { BB } \\
\text { diambil } \\
\text { untuk } \\
\text { Analisis } \\
\text { Gas BB }\end{array}$} \\
\hline & & & 275,85 & 278,55 & 2,70 & 7 (Suban) & \\
\hline & & & 282,15 & 283,15 & 1,00 & 8 (Petai) & \\
\hline & & & 297,42 & 300,95 & 2,58 & 9 & \\
\hline & & & 313,70 & 314,00 & 0,30 & 10 & \\
\hline
\end{tabular}

Tabel 2.

Hasil Perhitungan Desoprtion Test dan Analisis Gas Chromatograph

\begin{tabular}{|c|c|c|c|c|c|}
\hline No. & $\begin{array}{c}\text { LAPISAN } \\
\text { BATUBARA }\end{array}$ & $\begin{array}{c}\text { TOTAL } \\
\text { KANDUNGAN } \\
\text { GAS } \\
\text { (SCF/TON) }\end{array}$ & $\begin{array}{c}\text { TOTAL } \\
\text { KANDUNGAN } \\
\text { GAS } \\
\left(\mathbf{M}^{3} / \text { TON }\right)\end{array}$ & $\begin{array}{c}\text { KOMPOSISI } \\
\text { GAS METANA } \\
(\%)\end{array}$ & $\begin{array}{c}\text { KANDUNGAN } \\
\text { GAS } \\
\text { METANA } \\
\left(\mathbf{M}^{3} / \text { TON }\right)\end{array}$ \\
\hline 1 & Mangus & 40,10 & 1,14 & 42,21 & 0,48 \\
\hline 2 & Suban & 38,27 & 1,08 & 43,50 & 0,46 \\
\hline 3 & Petai & 35,10 & 0,99 & 20,66 & 0,20 \\
\hline
\end{tabular}


Tabel 3.

Hasil analisis adsorption isotherm conto batubara Canister 10 (Lapisan Mangus) dan Canister 23 (Lapisan Suban) - (Tim Pemboran Dalam Nibung, 2010)

\begin{tabular}{|c|c|c|c|c|c|}
\hline No & Conto Batubara & $\begin{array}{c}\text { Kedalaman } \\
(\mathbf{m})\end{array}$ & Suhu ${ }^{0} \mathrm{C}$ & $\begin{array}{c}\text { Volume } \\
\text { Langmuir, } \\
\text { VL ( } \mathbf{m}^{3} / \text { ton) }\end{array}$ & $\begin{array}{c}\text { Tekanan } \\
\text { Langmuir, } \\
\text { PL (psi) }\end{array}$ \\
\hline 1 & Canister 10 & $243,10-243,60$ & 30 & 12,43 & 474 \\
\hline 2 & Canister 23 & $275,60-276,00$ & 30 & 6,15 & 617 \\
\hline
\end{tabular}

Tabel 4.

Hasil analisis adsorption isotherm Canister 10, Lapisan Mangus

(Tim Pemboran Dalam Nibung, 2010)

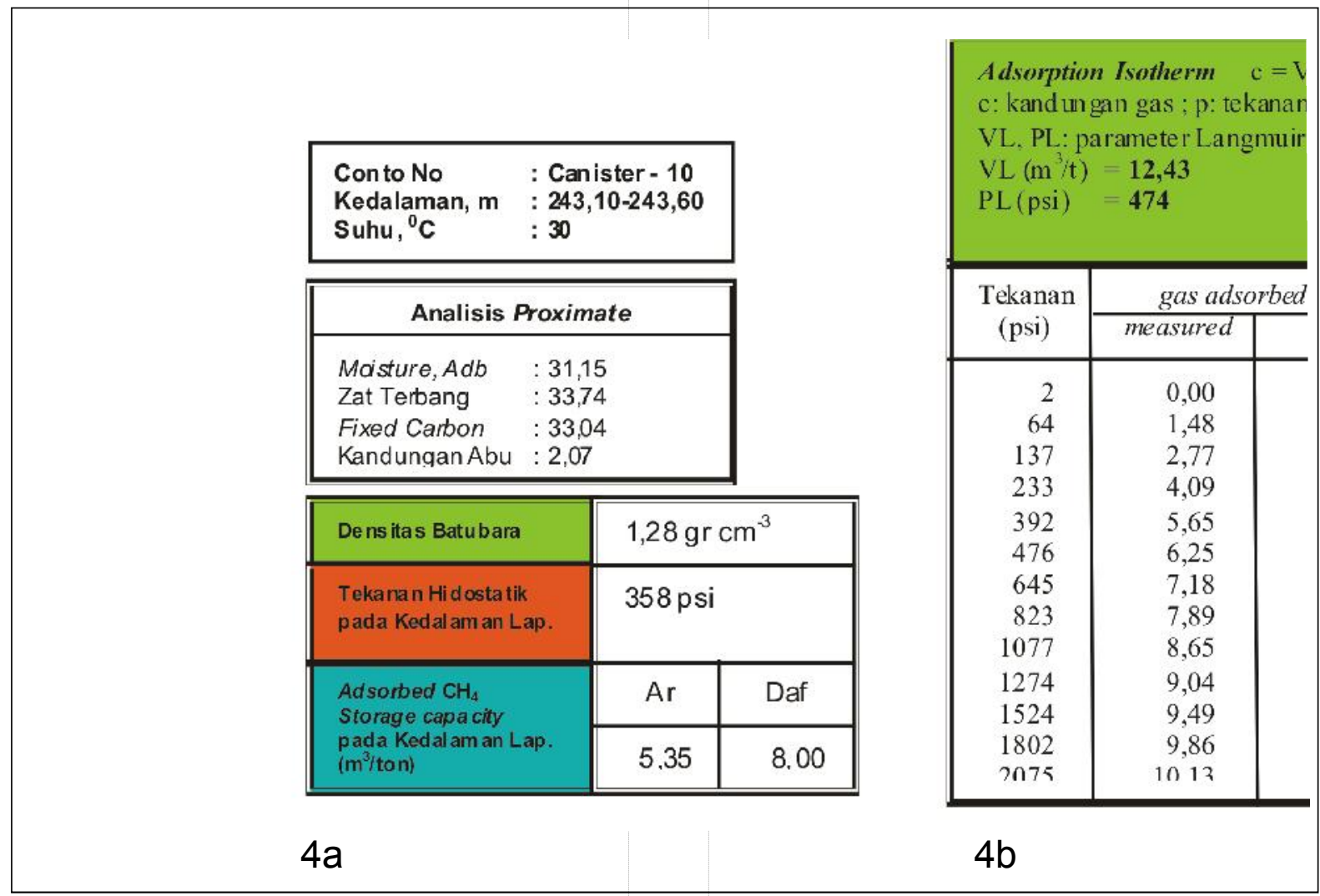




\section{MAKALAH ILMIAH}

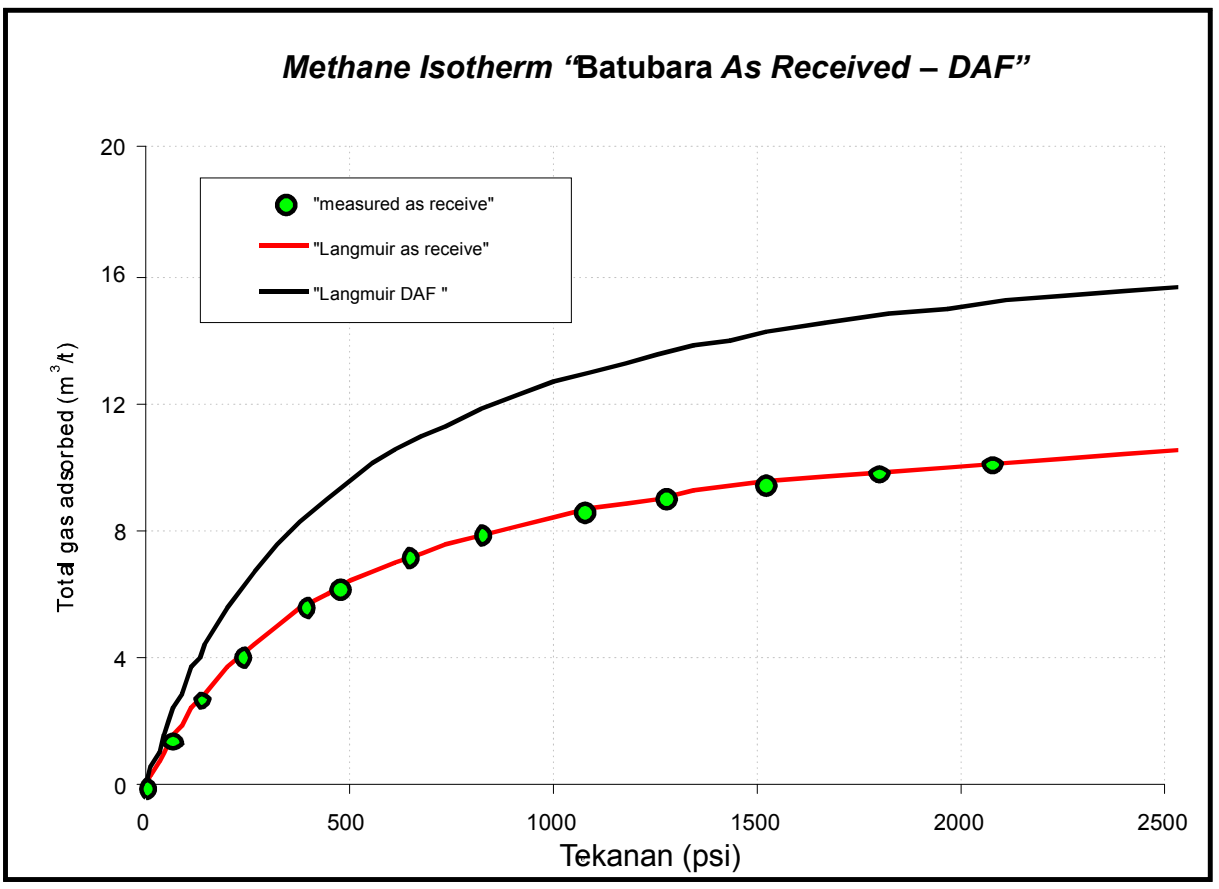

Gambar 3. Kurva Volume vs Tekanan Langmuir yang diperoleh dari conto Lapisan Mangus (Tim Pemboran Dalam Nibung, 2010)

Tabel 5.

Hasil analisis adsorption isotherm Canister 23, Lapisan Suban (Tim Pemboran Dalam Nibung, 2010)

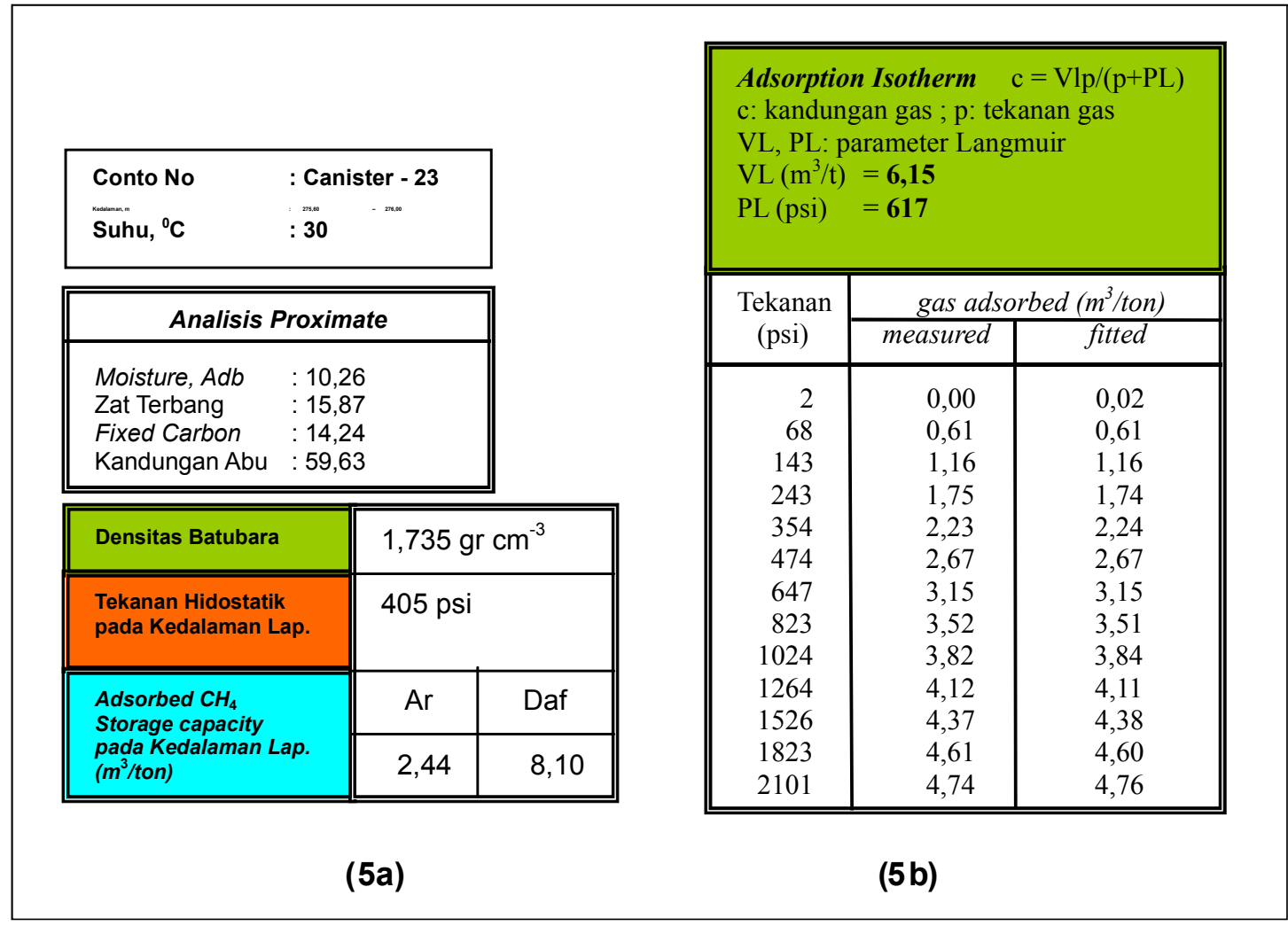


Methane Isotherm "Batubara As Received - DAF “

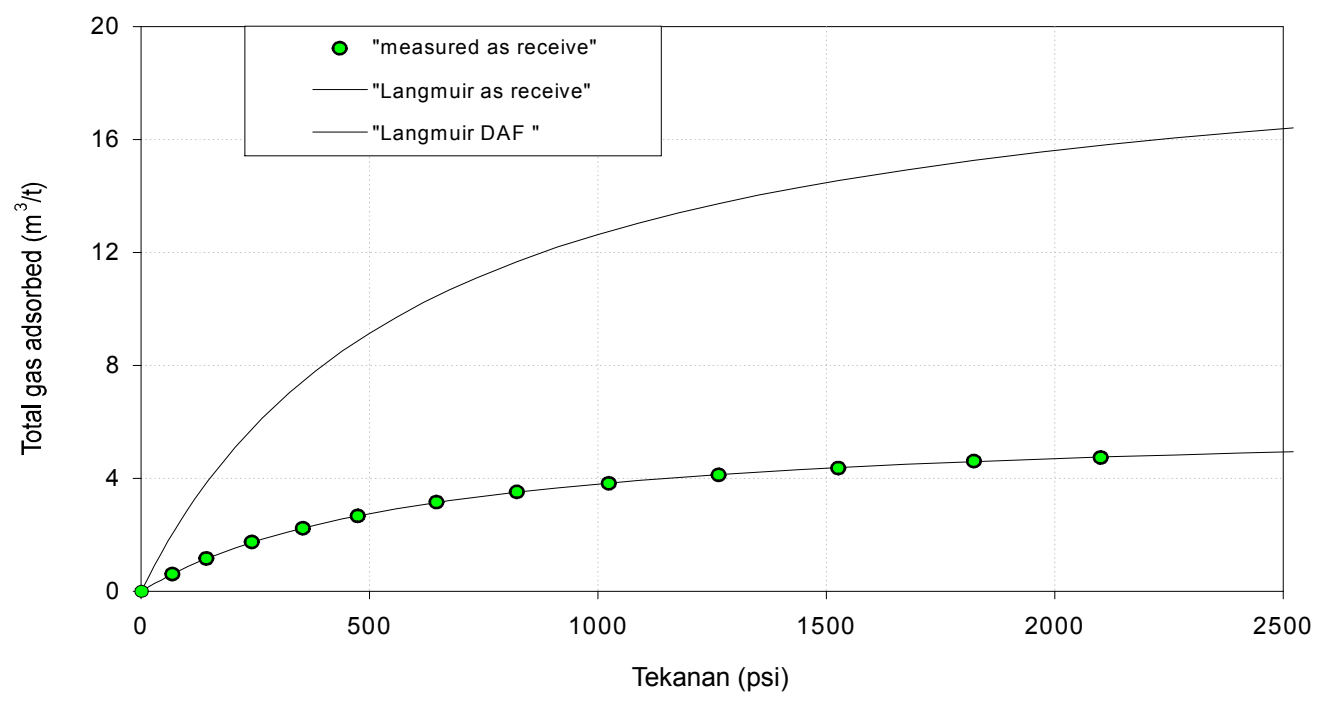

Gambar 4. Kurva Volume vs Tekanan Langmuir yang diperoleh dari conto Lapisan Suban (Tim Pemboran Dalam Nibung, 2010)

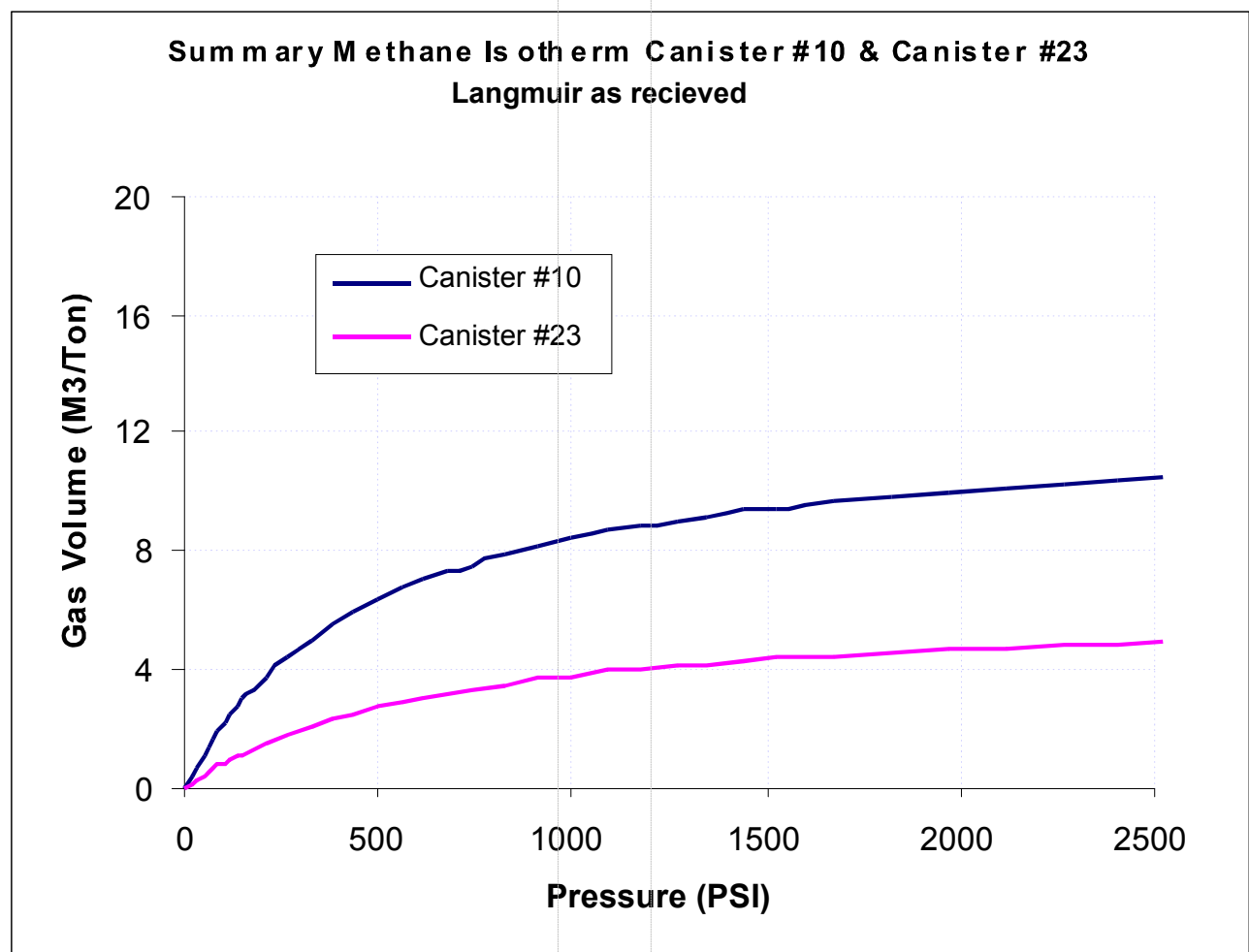

Gambar 5. Gabungan Kurva Volume vs Tekanan Langmuir yang diperoleh dari conto Canister 10 (Lapisan Mangus) dan Canister 23 (Lapisan Suban)

(Tim Pemboran Dalam Nibung, 2010) 
Tabel 6.

Hasil Analisis Kimia Nilai Kalori dan Kandungan Abu terhadap conto batubara Lapisan Mangus dan Suban

(Modifikasi dari Tim Pemboran Dalam Nibung, 2010)

\begin{tabular}{|c|c|c|c|c|}
\hline No & $\begin{array}{c}\text { Lapisan } \\
\text { Batubara }\end{array}$ & $\begin{array}{c}\text { Kedalaman } \\
(\mathbf{m})\end{array}$ & $\begin{array}{c}\text { Nilai } \\
\text { Kalori } \\
(\mathbf{k a l} / \mathbf{g r})\end{array}$ & $\begin{array}{c}\text { Kandungan } \\
\text { Abu (\%) }\end{array}$ \\
\hline 1 & Mangus & $237,58-251,22$ & $5542-6346$ & $2,25-17,26$ \\
\hline 2 & Suban & $275,85-278,55$ & $3161-6135$ & $3,00-48,54$ \\
\hline
\end{tabular}

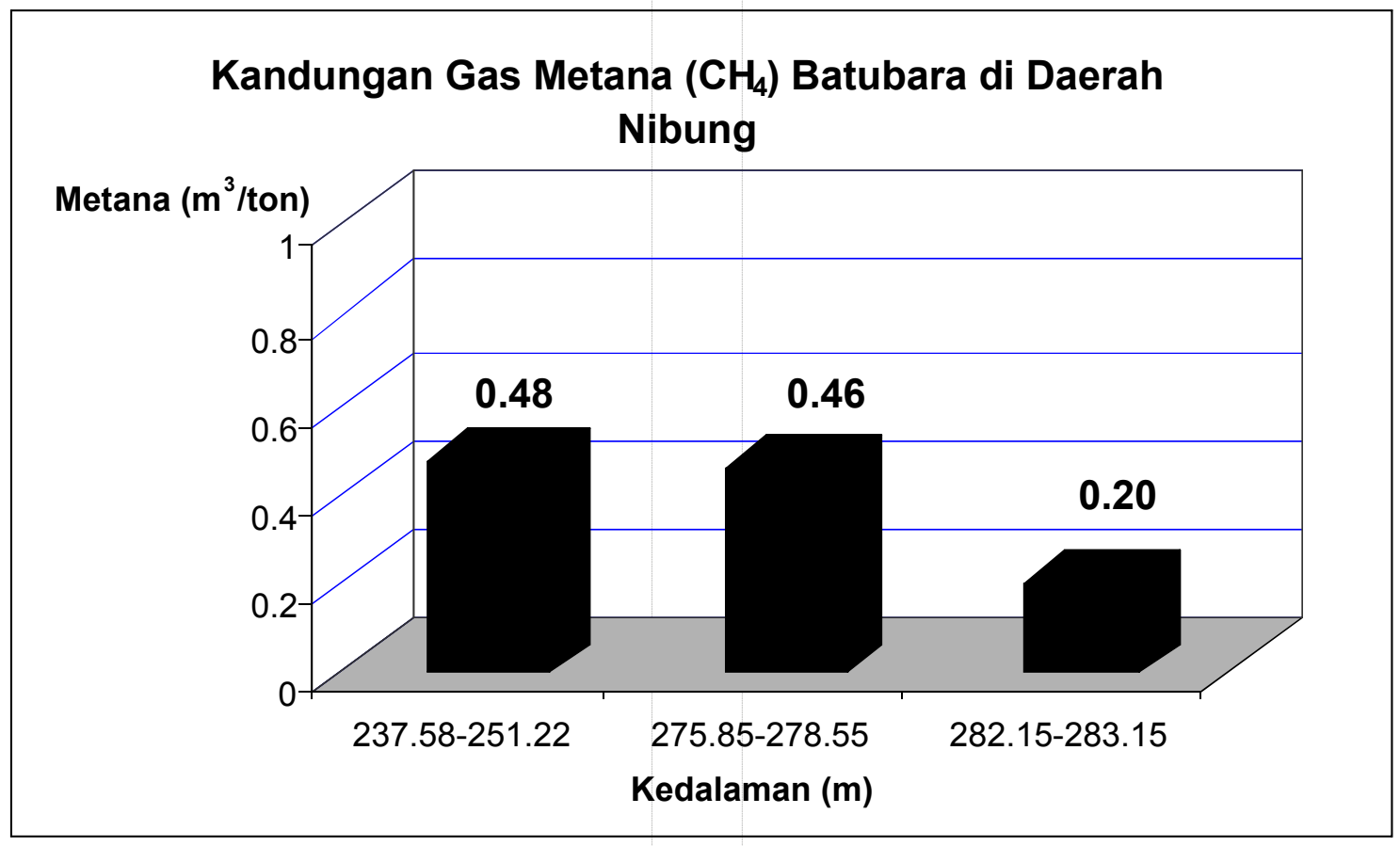

Gambar 6. Kurva kandungan gas metana batubara di daerah Nibung

\section{Pembahasan}

Dalam beberapa literatur disebutkan bahwa keterdapatan gas metana $\left(\mathrm{CH}_{4}\right)$ dalam batubara dipengaruhi oleh beberapa faktor. Salah satu faktor tersebut adalah kedalaman dimana semakin dalam lapisan batubara tersebut berada maka semakin besar pula kandungan gas metana yang terdapat didalamnya. Penelitian yang dilakukan di daerah Nibung menunjukkan hasil analisis yang berbeda dimana semakin dalam keterdapatan batubara maka semakin kecil kandungan gas metana dalam lapisan tersebut (Tabel 2, Gambar 6).

Berdasarkan hasil analisis adsorption isotherm yang dilakukan di dua lapisan yaitu Lapisan Mangus dan Suban, terlihat pula pada tabel 2 dan gambar 5 bahwa Lapisan Mangus memiliki kemampuan menyimpan gas lebih besar dibandingkan Lapisan Suban yang berada di bawahnya dimana Lapisan Mangus memiliki nilai sebesar $12,43 \mathrm{~m}^{3} / \mathrm{ton}$ dan Lapisan 
Suban hanya sebesar $6,15 \mathrm{~m}^{3} /$ ton. Di sisi lain, kandungan abu mencapai 2,09\% (Lapisan Mangus) dan 59,63 \% (Lapisan Suban). Lapisan Mangus memiliki kandungan abu yang lebih sedikit dibandingkan Lapisan Suban

Dari hasil analisis kimia diketahui pula bahwa pada Lapisan Suban Memiliki kisaran kandungan Abu yang cukup besar apabila dibandingkan dengan Lapisan Mangus. Hal ini dapat dilihat pada tabel 6 dimana Lapisan Suban memiliki kisaran kandungan abu antara 3,00 - 48,54 \% sedangkan Lapisan Mangus hanya memiliki kisaran kandungan abu antara 2,25 - 17,26 $\%$. Untuk nilai kalori di kedua lapisan tersebut dapat dikatakan tidak ada perbedaan yang cukup signifikan seperti terlihat pada tabel 6 .

Dari ketiga fakta tersebut diatas, selain ketebalan batubara, penulis dapat menyimpulkan pula bahwa kandungan abu merupakan faktor yang mempengaruhi jumlah kandungan gas metana batubara sedangkan kedalaman bukan merupakan suatu faktor yang mempengaruhi besar atau tidaknya kandungan gas metana batubara di Formasi Muaraenim daerah Nibung.

\section{Kesimpulan}

Sebanyak 26 conto batubara Lapisan Mangus, Suban dan Petai Formasi Muaraenim di titik bor NBG-01 di analisis kandungan gas metananya. Hasil perhitungan rata-rata menyebutkan bahwa kandungan gas metana $\left(\mathrm{Ch}_{4}\right)$ Lapisan Mangus $(13,64 \mathrm{~m})$ sebesar $0,48 \mathrm{~m}^{3} / \mathrm{ton}$, Lapisan Suban $(2,70 \mathrm{~m})$ sebesar $0,46 \mathrm{~m}^{3} /$ ton dan Lapisan Petai $(1,00 \mathrm{~m})$ sebesar 0,20 $\mathrm{m}^{3} /$ ton.

Kandungan Abu berdasarkan analisis adsorption isotherm diketahui bahwa untuk Lapisan Mangus dan Suban sebesar $2,07 \%$ dan $59,63 \%$

Selain ketebalan batubara, kandungan abu merupakan faktor terpenting yang menentukan jumlah kandungan gas metana batubara di Formasi Muaraenim daerah Nibung

\section{Ucapan Terima Kasih}

Ucapan terima kasih penulis sampaikan kepada Ir. Deddy Amarullah, Ir. Asep Suryana dan SM. Tobing, M.Sc yang telah memberikan bimbingan dan bantuan sehingga tulisan ini dapat terselesaikan.

\section{Daftar Pustaka}

Bayrak, Alan., 2010, Integrated Quantitative Basin Analysis for CBM Exploration, dipresentasikan pada workshop cbm di UNSRI Palembang tanggal 09 Desember 2010.

De Coster, G.L., 1974, The Geology of The Central and South Sumatra Basin. Proceeding Indonesia Petroleum Association, $4^{\text {th }}$ Annual Convention.

Pusat Sumber Daya Geologi (Tim Pemboran Dalam Nibung, 2010). Laporan Pemboran Dalam dan Pengukuran Kandungan Gas Pada Lapisan Batubara Daerah Nibung Kabupaten Musi Rawas, Provinsi Sumatera Selatan. Pusat Sumber Daya Geologi, Badan Geologi. Kementerian Energi Dan Sumber Daya Mineral, Bandung.

Suwarna, N., Suharsono, Gafoer, S., Amin, T. C., Kusnama dan Hermanto, B., 1992. Peta Geologi Lembar Sarolangun, Sumatra. Puslitbang Geologi, Bandung.

USGS, 2000. "Methode Gas Analysis", Colorado, USA

Wikipedia, 2011., Metana, (online), (http://www.id.wikipedia.org/wiki/Metana.html, diakses tanggal 16 Juni 2011) 